\title{
EFEKTIVITAS PENGHALANG VEGETASI SEBAGAI PEREDAM KEBISINGAN LALU LINTAS DI KAWASAN PENDIDIKAN JALAN AHMAD YANI PONTIANAK
}

\author{
Febi Resiana ${ }^{1}$, Mira S. Lubis ${ }^{2}$, Sarma Siahaan $^{1}$ \\ ${ }^{1}$ Program Studi Teknik Lingkungan Jurusan Teknik Sipil Fakultas Teknik Universitas Tanjungpura, Pontianak \\ ${ }^{2}$ Program Studi Perencanaan Wilayah \& Kota Jurusan Teknik Sipil Fakultas Teknik Universitas Tanjungpura, \\ Pontianak \\ ${ }^{3}$ Program Studi Kehutanan Fakultas Kehutanan Universitas Tanjungpura \\ Email: resyanafeby@yahoo.co.id
}

\begin{abstract}
ABSTRAK
Kawasan pendidikan memerlukan suasana yang tenang dari kebisingan. Kebisingan menyebabkan meningkatnya keluhan, menimbulkan gangguan kesehatan psikologis antara lain gangguan kenyamanan, gangguan komunikasi dan gangguan konsentrasi. Tingkat kebisingan akibat kendaraan lalu lintas dapat melebihi baku mutu kebisingan yang diperbolehkan untuk kawasan pendidikan, yaitu $55 \mathrm{dBA}$, sehingga perlu penanganan segera supaya kegiatan belajar mengajar tidak terganggu. Penanganan pereduksi kebisingan sebagai alternatif adalah dengan penghalang vegetasi. Tujuan penelitian mengetahui berapa efektivitas penghalang vegetasi yang terdapat di lokasi SMA Sultan Syarif Abdurrahman, SMK N 5 dan SD $S$ Bruder Nusa Indah di Jalan Ahmad Yani Pontianak. Penelitian ini dilakukan dengan mengukur tingkat kebisingan berdasarkan volume kendaraan lalu lintas dan mengukur volume kerimbunan daun. Tingkat kebisingan selama pengukuran adalah 69,78-75,86 dBA, melampaui baku mutu kebisingan kawasan pendidikan, $55 \mathrm{dBA}$. Total volume kerimbunan daun tertinggi terdapat di SMA Sultan Syarif Abdurrahman pada Plot 2 dengan $102593 \mathrm{~m}^{3}$, dengan hasil reduksi kebisingan oleh penghalang vegetasi tidak sebesar di SMK N 5 pada Plot 4 yang memiliki total volume kerimbunan $4877 \mathrm{~m}^{3}$. Disebabkan vegetasi di SMK N 5 Plot 4 memiliki kerapatan tumbuh vegetasi yang tinggi, kombinasi jenis dan ketinggian vegetasi yang memiliki kerapatan daun merata hingga permukaan tanah. Efektivitas vegetasi sebagai peredam kebisingan tergolong rendah, 3,69-16,04\%, disebabkan jenis vegetasi dengan ciri peredam kebisingan seperti memiliki daun tebal dan kaku, kerapatan daun yang tinggi, dan kombinasi tanaman dengan berbagai tingkatan tinggi, tidak ditanam secara merata sehingga penyerapan tidak maksimal. Perlunya mempertimbangan penempatan ruang publik dan privat pada kawasan pendidikan untuk mengurangi dampak kebisingan dari aktivitas kendaraan lalu lintas.
\end{abstract}

Kata Kunci : Kebisingan, Kawasan Pendidikan, Efektivitas Vegetasi

\section{ABSTRACT}

Education area needs quiet environment from noise. It can caused increase of complaint, psychologic health disorder such as disruption of comfort, communication and consentrate. The level of noise caused of vehicle activity can over standart of noise that permitted in education area, $55 \mathrm{dBA}$, so it needs solution to prevent disruption of learning activity. Alternative solution to reduce noise with vegetation barrier. The point of this researched was to find out how much effectiveness vegetation barrier in SMA Sultan Syarif Abdurrahman, SMK N 5 and SD S Bruder Nusa Indah at Jalan Ahmad Yani Pontianak. This research was did by measure level of noise based on volume of vehicles traffic activity and volume of canopy. Noise level during researched was 69,78-75,86 dBA, surpassed standart of noise for education area, 55 dBA. The highest total volume of canopy was SMA Sultan Syarif Abdurrahman in Plot 2, $102593 \mathrm{~m}^{3}$, with reduction by vegetation barrier was not as much as in SMK N 5 Plot 4 that had total volume of canopy $4877 \mathrm{~m}^{3}$. Because in SMK N 5 Plot 4 had high density plant, spesies combined and height of vegetation spread evenly until ground level. Effectiveness of vegetation as noise barrier was low, about 3,69-16,04\%, because spesies of vegetation that had characteristic of noise barrier such as thickness and hard of leaves, high density and combination of plant with different height, was not planted spread evenly so it was less absorption well. Needs to consider placement of public and private rooms in education area to decrease effect of noise from vehicles traffic activity.

Keywords : Noise, Education area, Effectiveness of vegetation 


\section{PENDAHULUAN}

Peningkatan jumlah kendaraan memiliki dampak terhadap penurunan kualitas udara yang dikhawatirkan berpengaruh pada kesehatan masyarakat. Perkembangan mesin kendaraan bermotor dalam beberapa hal justru meningkatkan polusi, baik udara maupun suara. Efek sampingnya menghasilkan polusi udara yang lebih pekat dan menimbulkan kebisingan yang tinggi. Kebisingan, bentuk pencemaran udara, adalah bunyi yang tidak diinginkan, suara keras yang tidak menyenangkan atau tidak diduga.

Kebisingan menyebabkan meningkatnya keluhan, jika tidak ditanggapi akan mengganggu masalah pada lokasi yang membutuhkan ketenangan seperti sekolah. Kegiatan belajar mengajar perlu memperhatikan kondisi lingkungan, zona pendidikan memerlukan suasana yang tenang dari kebisingan. Vegetasi digunakan sebagai alternatif pereduksi kebisingan yang ramah lingkungan, memberikan keindahan dilihat dari aspek visual, mampu menyerap dan menyebarkan energi bunyi.

Lokasi pendidikan yang dilakukan penelitian adalah SMA Sultan Syarif Abdurrahman dan SMK N 5, kedua sekolah ini berdekatan dan berada di Jalan Ahmad Yani, sedangkan sebagai lokasi kontrol adalah SD S Bruder Nusa Indah. Penelitian ini bertujuan untuk mengetahui seberapa efektifnya penghalang vegetasi terhadap pengurangan kebisingan yang terdapat di lokasi sekolah dengan menghitung volume kerimbunan daunnya.

\section{METODOLOGI PENELITIAN}

Lokasi penelitian berada di SMA Sultan Syarif Abdurrahman, SMK N 5 dan SD S Bruder Nusa Indah Jalan Ahmad Yani Pontianak. Pengambilan data kebisingan dilakukan pada dua kondisi waktu, yaitu waktu maksimum volume kendaraan dan waktu minimum volume kendaraan. Penelitian dilakukan dalam 3 hari Senin, 4 Agustus 2014, Jumat, 7 Agustus 2014 dan Sabtu, 8 Agustus 2014.
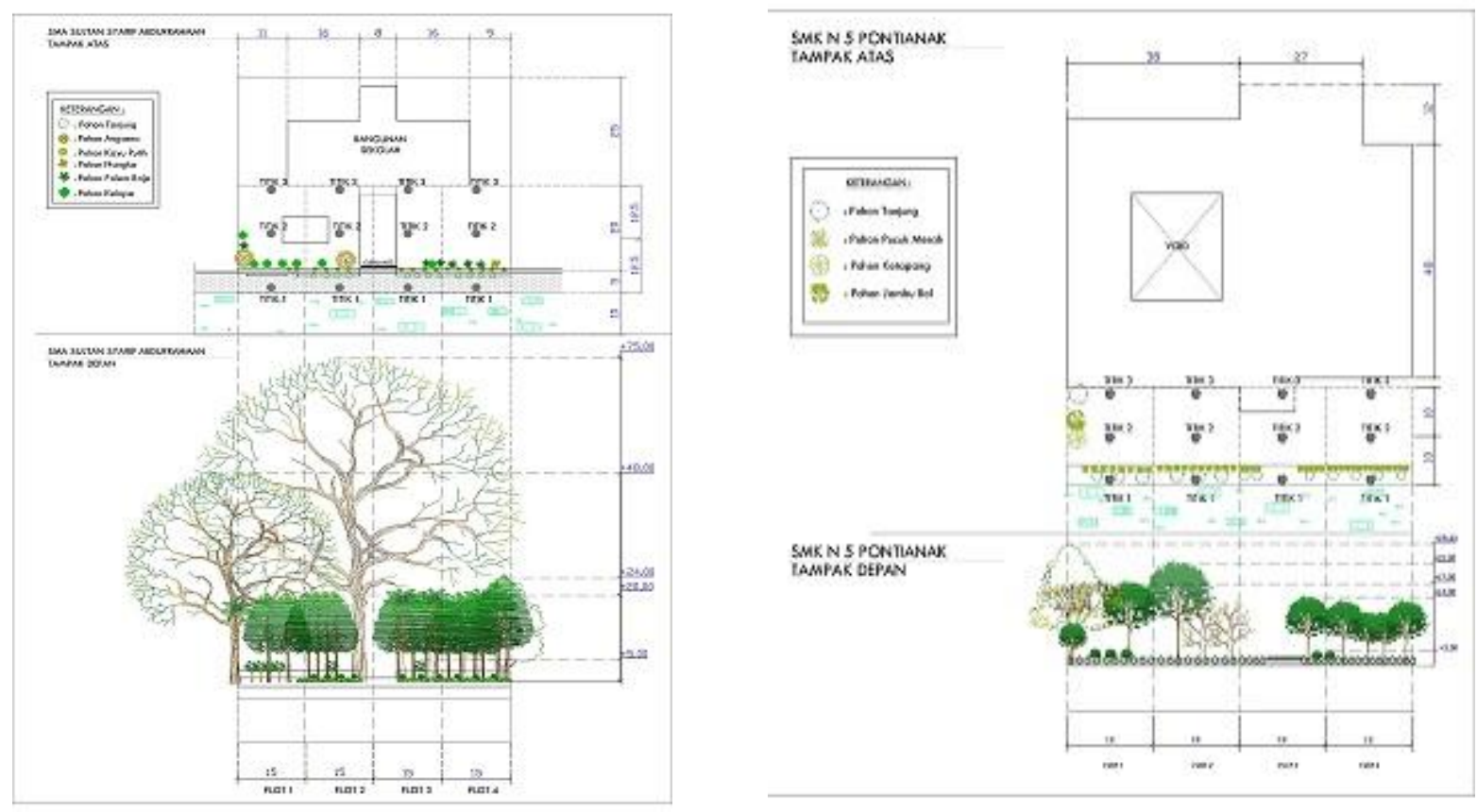

Gambar. 1. Tampak Atas dan Depan SMA Sultan Syarif Abdurrahman dan SMK N 5 Pontianak 


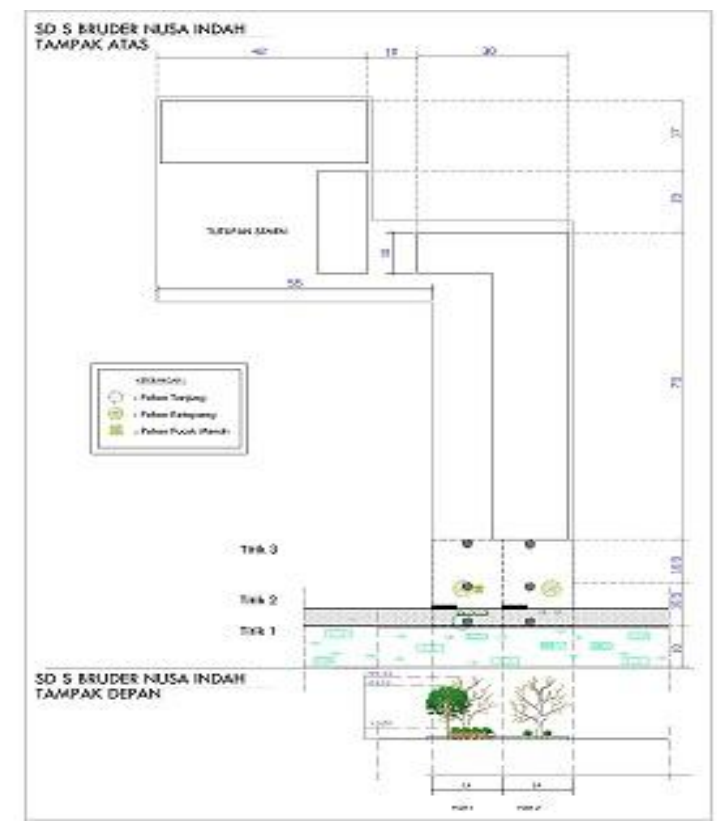

Gambar 2. Tampak Atas dan Depan SD S Bruder Nusa Indah

\section{A. Pengumpulan Data}

1) Perhitungan Volume Kendaraan

Dilakukan setiap 10 menit, pada hari Senin, Jumat, dan Sabtu. Senin, mewakili hari kerja, Jumat mewakili waktu aktivitas siang yang diasumsikan cukup tinggi berkenaan dengan waktu istirahat siang, waktu pulang sekolah, dan shalat Jumat, dan Sabtu, mewakili hari libur kerja. Waktu pengamatan dilakukan sebanyak tiga kali, pagi (06.00-09.00), siang (10.00-13.00), dan sore (14.00-17.00).

2) Data Vegetasi

Meliputi jenis (nama lokal dan ilmiah vegetasi), jumlah, tinggi cabang bebas dan tinggi pohon, diameter kanopi, bentuk kanopi, dan persen kerimbunan. Pengumpulan data vegetasi ini untuk menghitung volume kerimbunan daun.

3) Pengukuran Tingkat Kebisingan

Dilakukan dengan cara sederhana, dengan sound level meter biasa diukur tingkat tekanan bunyi sesaat $d B(A)$ selama 15 menit untuk tiap pengukuran. Pembacaan dilakukan setiap 5 detik. Dilakukan oleh 2 orang, yaitu seorang melihat waktu dan memberikan aba-aba pembacaan tingkat kebisingan sesaat per lima detik dalam waktu 15 menit dan orang kedua mencatat tingkat kebisingan sesaat dari sound level meter.

\section{B. Analisis Data}

1) Analisa Kebisingan

Data kebisingan yang didapat kemudian dianalisa dengan perhitungan Leq, dengan persamaan (Pusat Pendidikan dan Pelatihan MenLH, 2009) :

keterangan :

$$
\text { Leq }=10 \log \frac{1}{180} \Sigma n k 10^{0,1 . l i} \mathrm{~dB} \text { atau Leq }=10 \log \frac{1}{180} \Sigma 10^{0,1 . l i} \mathrm{~dB}
$$

$L_{\text {eq }}=$ nilai tingkat kebisingan dari kebisingan yang berubah - ubah (fluktuatif) selama waktu tertentu, yang setara dengan tingkat kebisingan dari kebisingan yang steady pada waktu yang sama, pada interval antara jam i dan jam $\mathrm{j}$,

$n_{k}=$ jumlah data yang mempunyai $L_{k}$,

$\mathrm{I}_{\mathrm{i}}=$ level pada data ke-i. 
2) Analisa Vegetasi

Data tingkat kebisingan yang diperoleh digunakan untuk menentukan nilai reduksi kebisingan yang dihitung dengan menggunakan rumus (Widagdo, 1998)

Efektivitas reduksi dengan rumus :

$$
\mathrm{N}_{\mathrm{RV}}=\mathrm{K}_{\mathrm{DV}}-\mathrm{K}_{\mathrm{BV}}
$$

\section{Keterangan}

$$
\text { Efektivitas Reduksi }=\frac{K_{D V}-K_{B V}}{K_{D V}} \times 100 \%
$$

$\mathrm{N}_{\mathrm{RV}}=$ Nilai reduksi kebisingan pada area bervegetasi ( $\mathrm{dB}$ )

$\mathrm{K}_{\mathrm{DV}}=$ Tingkat kebisingan di titik pengamatan area depan vegetasi (dB)

$\mathrm{K}_{\mathrm{BV}}=$ Tingkat kebisingan di titik pengamatan area belakang vegetasi (dB)

Untuk analisa vegetasinya dilakukan perhitungan untuk mengetahui volume kerimbunan daun dan kerapatan tanaman, dengan perhitungan sebagai berikut,

Tabel 1. Volume Kerimbunan Daun sesuai Bentuk Kanopi

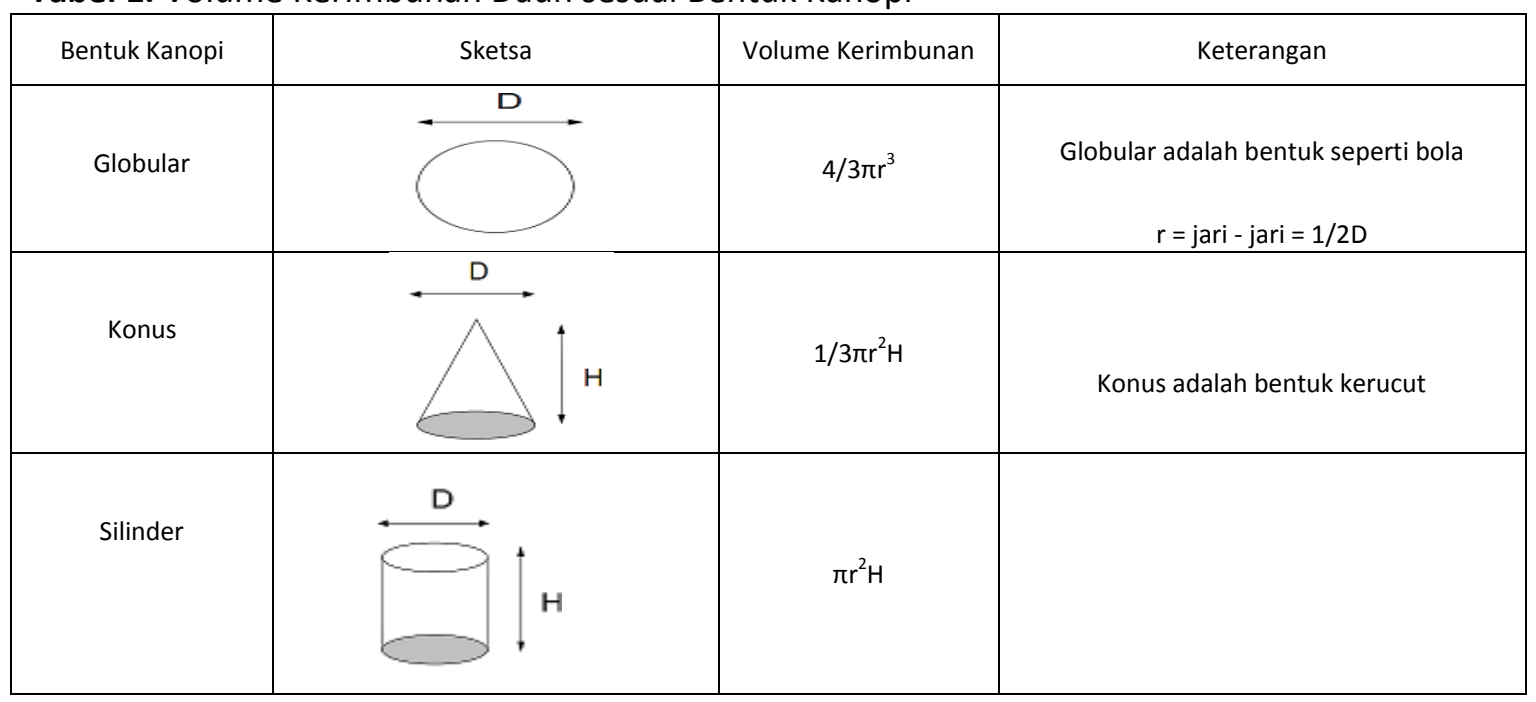

\section{HASIL DAN PEMBAHASAN}

\section{1) Volume Kendaraan Lalu Lintas dan Tingkat Kebisingan}

Penelitian ini membagi waktu pengukuran menjadi dua, yaitu kondisi lalu lintas saat maksimum dan kondisi minimum,

Tabel 2. Tingkat Kebisingan Volume Kendaraan Maksimum

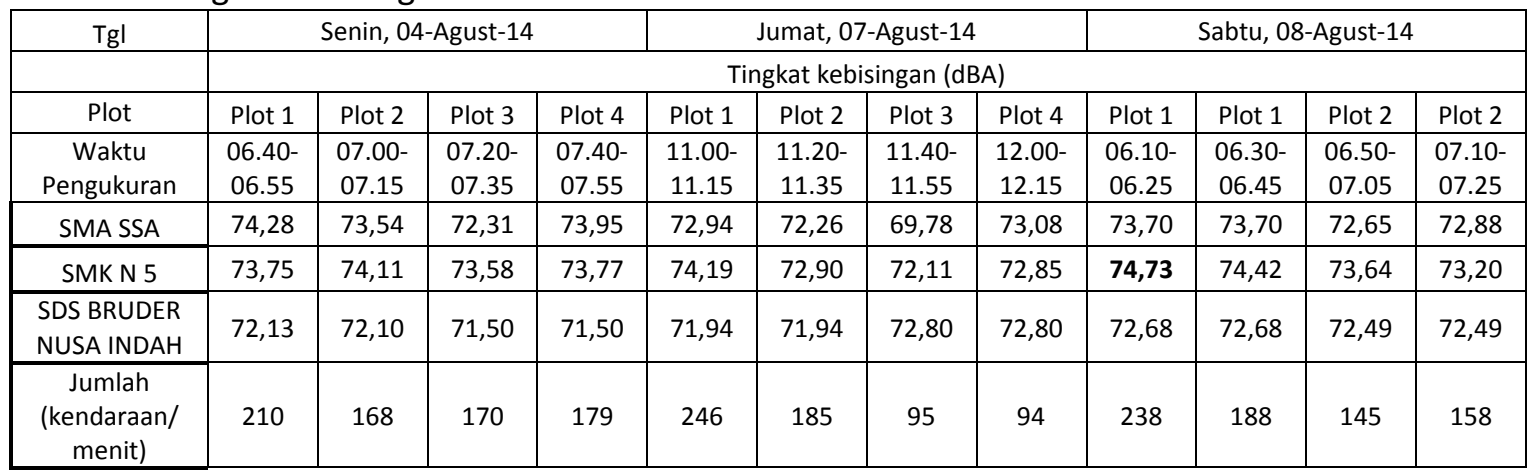


Tabel 3. Tingkat Kebisingan Volume Kendaraan Minimum

\begin{tabular}{|c|c|c|c|c|c|c|c|c|c|c|c|c|}
\hline $\mathrm{Tgl}$ & \multicolumn{4}{|c|}{ Senin, 04-Agust-14 } & \multicolumn{4}{|c|}{ Jumat, 07-Agust-14 } & \multicolumn{4}{|c|}{ Sabtu, 08-Agust-14 } \\
\hline & \multicolumn{12}{|c|}{ Tingkat kebisingan (dBA) } \\
\hline Plot & Plot 1 & Plot 2 & Plot 3 & Plot 4 & Plot 1 & Plot 2 & Plot 3 & Plot 4 & Plot 1 & Plot 1 & Plot 2 & Plot 2 \\
\hline $\begin{array}{c}\text { Waktu } \\
\text { Pengukuran }\end{array}$ & $\begin{array}{l}10.50- \\
11.05\end{array}$ & $\begin{array}{l}11.10- \\
11.25\end{array}$ & $\begin{array}{l}11.30- \\
11.45\end{array}$ & $\begin{array}{l}11.50- \\
12.05\end{array}$ & $\begin{array}{l}12.30- \\
12.45\end{array}$ & $\begin{array}{l}12.50- \\
13.05\end{array}$ & $\begin{array}{l}13.10- \\
13.25\end{array}$ & $\begin{array}{l}13.30- \\
13.45\end{array}$ & $\begin{array}{l}15.40- \\
15.55\end{array}$ & $\begin{array}{l}16.00- \\
16.15\end{array}$ & $\begin{array}{l}16.20- \\
16.35\end{array}$ & $\begin{array}{l}16.40- \\
16.55\end{array}$ \\
\hline SMA SSA & 74,74 & 72,73 & 72,49 & 72,72 & 72,86 & 74,93 & 71,45 & 70,39 & 72,64 & 72,86 & 73,21 & 72,52 \\
\hline SMK N 5 & 74,69 & 72,53 & 73,67 & 73,50 & 74,88 & 74,93 & 73,42 & 73,52 & 75,86 & 74,34 & 73,96 & 74,45 \\
\hline $\begin{array}{l}\text { SDS BRUDER } \\
\text { NUSA INDAH }\end{array}$ & 71,92 & 71,92 & 71,46 & 71,46 & 71,60 & 71,60 & 71,36 & 71,36 & 70,76 & 70,76 & 70,94 & 70,94 \\
\hline $\begin{array}{c}\text { Jumlah } \\
\text { (kendaraan/ } \\
\text { menit) }\end{array}$ & 113 & 178 & 176 & 187 & 110 & 111 & 103 & 92 & 56 & 101 & 100 & 86 \\
\hline
\end{tabular}

Berdasarkan Tabel 2 dan 3., tingkat kebisingan tertinggi waktu volume kendaraan maksimum pada Sabtu, 8 Agustus 2014, adalah 74,73 dBA dengan volume kendaraan 238 unit kendaraan/menit. Tingkat kebisingan tertinggi waktu volume kendaraan minimum juga pada Sabtu, 8 Agustus 2014, adalah 75,86 dBA dengan volume kendaraan 56 unit kendaraan/menit.

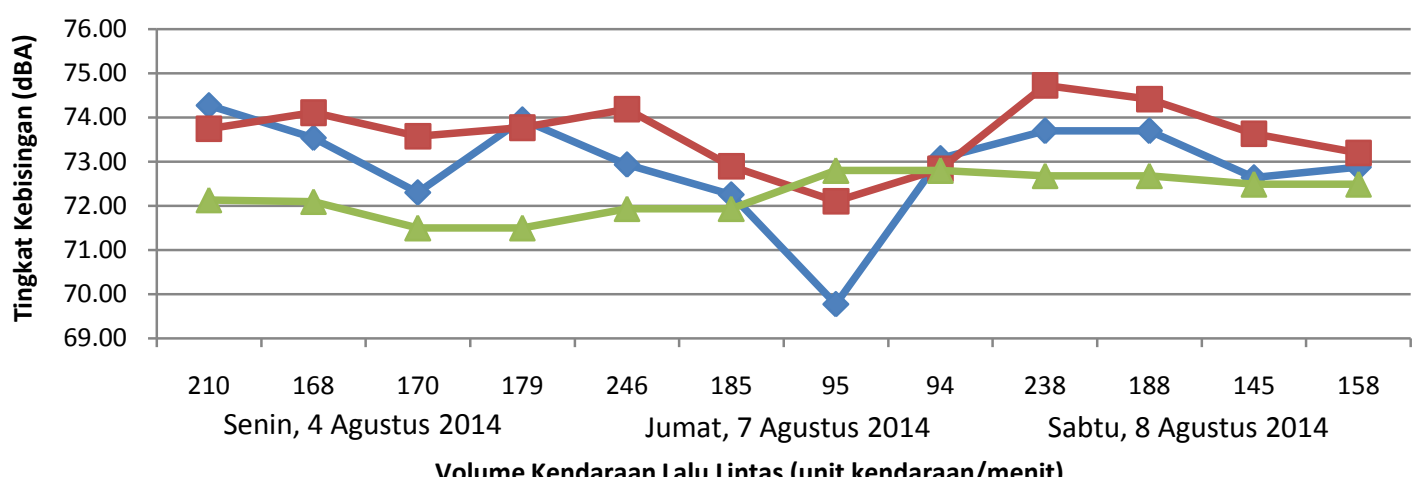

Volume Kendaraan Lalu Lintas (unit kendaraan/menit)

$\longrightarrow$ SMA SSA $\longrightarrow$ SMK N $5 \longrightarrow$ SDS BRUDER NUSA INDAH

Gambar 3. Grafik Volume Kendaraan Lalu Lintas Maksimum dan Tingkat Kebisingan

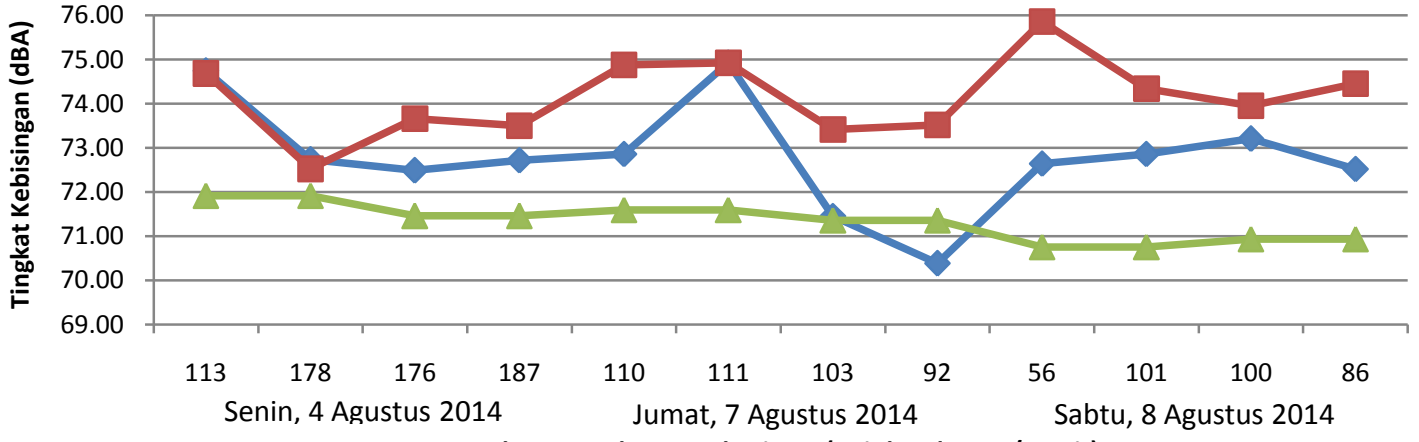

Volume Kendaraan Lalu Lintas (unit kendaraan/menit)

$\longrightarrow$ SMA SSA $\longrightarrow$ SMK N $5 \longrightarrow$ SDS BRUDER NUSA INDAH

Gambar 4. Grafik Volume Kendaraan Lalu Lintas Minimum dan Tingkat Kebisingan

Berdasarkan Gambar 3 dan 4, Tingkat kebisingan tertinggi waktu maksimum dan minimum berada di SMK N 5, berdekatan dengan perempatan jalan dan lampu lalu lintas (ruas jalan A Yani menuju jalan KH Ahmad Dahlan), saat pengambilan sampel, kendaraan berada pada kondisi diam dan mengalami kemacetan hingga $\pm 100 \mathrm{~m}$ dari lampu lalu lintas. Bunyi yang 
ditimbulkan oleh lalu lintas adalah bunyi dengan tingkat suara yang tidak konstan (Primanita $M$, 2012). Waktu maksimum tingkat kebisingannya pada Sabtu, 8 Agustus 2014 adalah 74,73 dBA dengan volume kendaraan 238 unit kendaraan/menit, meskipun bukan volume tertinggi, tapi faktor lokasi sampel yang berdekatan dengan perempatan jalan dan lampu lalu lintas, menjadi alasan bunyi yang dihasilkan berasal dari klakson dan pengereman kendaraan dimana kecepatan kendaraan menurun. Hasil lainnya pada Sabtu, 8 Agustus 2014 waktu minimum, dengan volume kendaraan 56 unit kendaraan/menit, mampu menimbulkan tingkat bising yang tinggi, yaitu 75,86 dBA. Kebisingan kendaraan bermotor ditimbulkan dari beberapa sumber, seperti mesin, transmisi, rem, klakson, knalpot, dan gesekan roda dengan jalan. Dengan ruas jalan yang sepi, kemungkinan pengendara kendaraan memacu kecepatan tinggi, sehingga menimbulkan kebisingan yang besar. Kebisingan akibat gesekan roda dengan jalan tergantung pada jenis ban, kecepatan kendaraan. Kecepatan kendaraan, semakin cepat lajunya, semakin tinggilah kebisingan yang dihasilkan (Christina E, 2005).

\section{2) Volume Kerimbunan Daun dan Tingkat Kebisingan}

\section{a. SMA Sultan Syarif Abdurrahman}

Vegetasi yang terdapat di lokasi ini bervariasi mulai dari tanaman perdu sampai pohon, seperti Angsana (Pterocarpus indicus), Kayu Putih (Melaleuca leucadendra), Kelapa (Cocos nucifera), Nangka (Artocarpus heterophyllus), Tanjung (Mimusops elengi), Palem Raja (Roystonea regia), dan tanaman perdu Bunga Bakung (Hymenocallis), mengacu pada Gambar 1. Berikut hasil volume kerimbunan dan reduksi kebisingannya,

Tabel 4. Volume Kerimbunan Daun dan Reduksi Kebisingan Vegetasi Waktu Maksimum dan Minimum SMA Sultan Syarif Abdurrahman

\begin{tabular}{|c|c|c|c|c|c|c|}
\hline Plot & Waktu Penelitian & $\begin{array}{c}\text { Volume } \\
\text { Kerimbunan } \\
\text { Daun }\left(\mathrm{m}^{3}\right)\end{array}$ & $\begin{array}{c}\text { Reduksi } \\
\text { Kebisingan } \\
\text { Vegetasi Waktu } \\
\text { Maksimum } \\
\text { (dBA) }\end{array}$ & $\begin{array}{c}\text { Reduksi } \\
\text { Kebisingan } \\
\text { Vegetasi Waktu } \\
\text { Minimum (dBA) }\end{array}$ & $\begin{array}{c}\text { Efektivitas } \\
\text { Vegetasi Reduksi } \\
\text { Kebisingan } \\
\text { Waktu } \\
\text { Maksimum (\%) } \\
\end{array}$ & $\begin{array}{c}\text { Efektivitas } \\
\text { Vegetasi Reduksi } \\
\text { Kebisingan } \\
\text { Waktu Minimum } \\
(\%) \\
\end{array}$ \\
\hline \multirow{3}{*}{1} & Senin, 4 Agustus 2014 & \multirow{3}{*}{7906} & 7,12 & 7,65 & 9,58 & 10,23 \\
\hline & Jumat, 7 Agustus 2014 & & 7,11 & 7,73 & 9,74 & 10,61 \\
\hline & Sabtu, 8 Agustus 2014 & & 6,02 & 6,04 & 8,16 & 8,32 \\
\hline \multirow{3}{*}{2} & Senin, 4 Agustus 2014 & \multirow{3}{*}{102593} & 7,13 & 6,81 & 9,70 & 9,36 \\
\hline & Jumat, 7 Agustus 2014 & & 6,83 & 7,34 & 9,45 & 9,79 \\
\hline & Sabtu, 8 Agustus 2014 & & 6,67 & 5,57 & 9,06 & 8,32 \\
\hline \multirow{3}{*}{3} & Senin, 4 Agustus 2014 & \multirow{3}{*}{42,47} & 6,63 & 5,97 & 9,16 & 8,24 \\
\hline & Jumat, 7 Agustus 2014 & & 3,84 & 6,60 & 5,50 & 9,24 \\
\hline & Sabtu, 8 Agustus 2014 & & 5,23 & 5,35 & 7,20 & 7,31 \\
\hline \multirow{3}{*}{4} & Senin, 4 Agustus 2014 & \multirow{3}{*}{3203,66} & 7,63 & 7,68 & 10,32 & 10,55 \\
\hline & Jumat, 7 Agustus 2014 & & 8,14 & 5,54 & 11,13 & 7,88 \\
\hline & Sabtu, 8 Agustus 2014 & & 6,81 & 5,49 & 9,34 & 7,57 \\
\hline
\end{tabular}

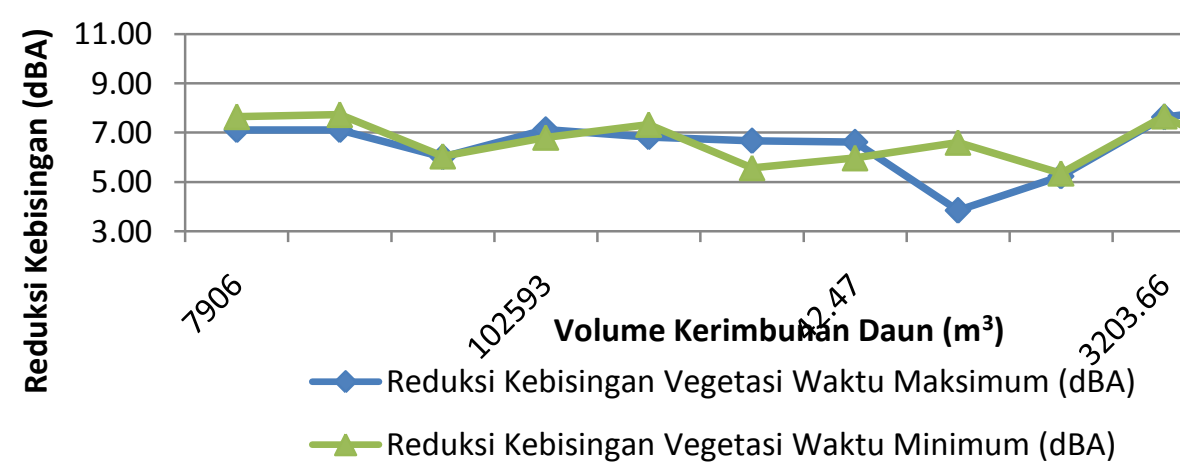

Gambar 5. Grafik Hubungan Volume Kerimbunan Daun terhadap Reduksi Kebisingan SMA Sultan Syarif Abdurrahman 
Vegetasi pada Plot 2 memiliki volume kerimbunan daun tertinggi, yaitu $102593 \mathrm{~m}^{3}$, mampu mereduksi kebisingan 5,57-7,34 dBA. Meskipun pada Plot 2 merupakan volume kerimbunan daun tertinggi, tapi reduksi kebisingan oleh vegetasi justru lebih tinggi pada Plot 4 dengan 5,49-8,14 dBA. Mengacu pada Gambar 1, Plot 4 terdiri dari Kayu Putih, Nangka, Palem Raja dan Tanjung. Vegetasi pada plot 4 memiliki tajuk daun yang rindang seperti Kayu Putih dan Tanjung, dan bentuk daun yang tebal dan kaku seperti Nangka, seperti yang disampaikan oleh Widagdo, 1998, bahwa kemampuan tanaman mereduksi kebisingan juga dipengaruhi oleh ketebalan dan kelenturan daun, berkaitan dengan kemudahan daun untuk bergerak karena angin dan energi suara. Adanya gerakan daun dapat menyebabkan perubahan posisi antardaun memungkinkan suara menembus ke dalam vegetasi dan selanjutnya lolos ke belakang vegetasi. Energi suara yang menumbuk selanjutnya dipantulkan, diserap, disebarkan, dibelokkan, atau diteruskan oleh daun sebagai bidang penahan suara pada vegetasi. Sedangkan Pohon Angsana dan Kayu Putih memang memiliki tajuk yang rindang, tapi luas daunnya kecil. Semakin kecil bidang penahan maka semakin besar kemungkinan suara lolos menembus kebelakang vegetasi (Liesa A, 2001).

\section{b. SMK N 5}

Vegetasi yang terdapat di lokasi ini seperti Jambu Bol (Syzygium malaccense), Ketapang (Terminalia catappa), Pucuk Merah (Oleina syzygium), dan Tanjung (Mimusops elengi), mengacu pada Gambar 1. Berikut hasil volume kerimbunan daun dan reduksi kebisingannya,

Tabel 5. Volume Kerimbunan Daun dan Reduksi Kebisingan Vegetasi Waktu Maksimum dan Minimum SMK N 5

\begin{tabular}{|c|c|c|c|c|c|c|}
\hline Plot & Waktu Penelitian & $\begin{array}{l}\text { Volume } \\
\text { Kerimbunan } \\
\text { Daun }\left(\mathrm{m}^{3}\right)\end{array}$ & $\begin{array}{c}\text { Reduksi } \\
\text { Kebisingan } \\
\text { Vegetasi Waktu } \\
\text { Maksimum } \\
\text { (dBA) }\end{array}$ & $\begin{array}{c}\text { Reduksi } \\
\text { Kebisingan } \\
\text { Vegetasi Waktu } \\
\text { Minimum (dBA) }\end{array}$ & $\begin{array}{c}\text { Efektivitas } \\
\text { Vegetasi Reduksi } \\
\text { Kebisingan } \\
\text { Waktu } \\
\text { Maksimum (\%) }\end{array}$ & $\begin{array}{c}\text { Efektivitas } \\
\text { Vegetasi Reduksi } \\
\text { Kebisingan } \\
\text { Waktu Mnimum } \\
(\%)\end{array}$ \\
\hline \multirow{3}{*}{1} & Senin, 4 Agustus 2014 & \multirow{3}{*}{10012,34} & 6,65 & 7,68 & 9,01 & 10,28 \\
\hline & Jumat, 7 Agustus 2014 & & 6,21 & 7,86 & 8,37 & 10,49 \\
\hline & Sabtu, 8 Agustus 2014 & & 7,96 & 7,82 & 10,65 & 10,31 \\
\hline \multirow{3}{*}{2} & Senin, 4 Agustus 2014 & \multirow{3}{*}{4719,88} & 7,38 & 5,95 & 9,96 & 8,20 \\
\hline & Jumat, 7 Agustus 2014 & & 6,70 & 7,68 & 9,19 & 10,25 \\
\hline & Sabtu, 8 Agustus 2014 & & 7,16 & 7,53 & 9,62 & 10,13 \\
\hline \multirow{3}{*}{3} & Senin, 4 Agustus 2014 & \multirow{3}{*}{1843,84} & 4,85 & 6,04 & 6,59 & 8,20 \\
\hline & Jumat, 7 Agustus 2014 & & 5,30 & 6,93 & 7,35 & 9,43 \\
\hline & Sabtu, 8 Agustus 2014 & & 6,97 & 6,81 & 9,47 & 9,21 \\
\hline \multirow{3}{*}{4} & Senin, 4 Agustus 2014 & \multirow{3}{*}{4877,41} & 7,04 & 7,37 & 9,54 & 10,02 \\
\hline & Jumat, 7 Agustus 2014 & & 6,92 & 8,70 & 9,50 & 11,84 \\
\hline & Sabtu, 8 Agustus 2014 & & 7,39 & 10,81 & 10,09 & 14,52 \\
\hline
\end{tabular}

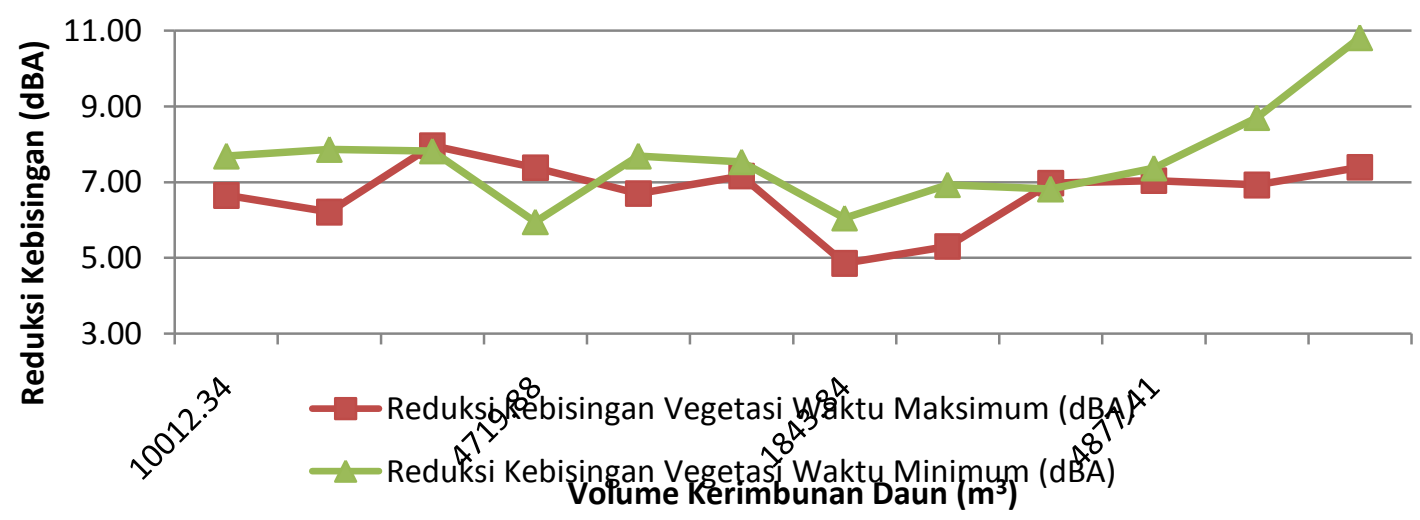

Gambar 6. Grafik Hubungan Volume Kerimbunan Daun dan Reduksi Kebisingan Vegetasi SMK N 5 
Plot 4 memiliki tingkat reduksi kebisingan tertinggi, yaitu 6,92-10,81 dBA, dengan volume kerimbunan daun $4877,41 \mathrm{~m}^{3}$. Padahal Plot 1 memiliki volume kerimbunan daun lebih tinggi dari Plot 4, berdasarkan Gambar 1, pada Plot 1 untuk jenis tanaman Jambu Bol, Ketapang dan Tanjung berada di dalam area sekolah, sedangkan pengurangan kebisingan oleh vegetasi pada penelitian untuk tanaman yang ditanam pada jalur yang sama. Vegetasi Plot 4 memiliki massa daun padat dengan pola daun menyebar hingga ke permukaan tanah, sehingga lebih efektif mereduksi kebisingan (Carpenter et al, 1975 diacu dalam Liesa A, 2001). Selain itu vegetasi di Plot 4 ditanam membentuk posisi sejajar, rapat, dan berurutan, sehingga dapat mengurangi kebisingan yang lebih besar (Berrnatzky, 1978 dalam Retno Sujano, 2004). Kombinasi tinggi vegetasi juga punya peran terhadap pengurangan kebisingan, dengan penanaman tinggi yang berbeda, maka penyerapan suara dapat dilakukan jika sumber suara berasal dari bawah atau atas.

\section{c. SD S Bruder Nusa Indah}

Vegetasi seperti Ketapang (Terminalia catappa), Pucuk Merah (Oleina syzygium), Tanjung (Mimusops elengi), Andong Merah (Cordyline) dan Puring (Codiaeum variegatum), mengacu pada Gambar 2. Berikut hasil perhitungan volume kerimbunan daun dan reduksi kebisingannya,

Tabel 6. Volume Kerimbunan Daun dan Reduksi Kebisingan Vegetasi SD S Bruder Nusa Indah

\begin{tabular}{|c|c|c|c|c|c|c|}
\hline Plot & Waktu Penelitian & $\begin{array}{l}\text { Volume } \\
\text { Kerimbunan } \\
\text { Daun }\left(\mathrm{m}^{3}\right)\end{array}$ & $\begin{array}{c}\text { Reduksi } \\
\text { Kebisingan } \\
\text { Vegetasi Waktu } \\
\text { Maksimum } \\
\text { (dBA) }\end{array}$ & $\begin{array}{c}\text { Reduksi } \\
\text { Kebisingan } \\
\text { Vegetasi Waktu } \\
\text { Minimum (dBA) }\end{array}$ & $\begin{array}{c}\text { Efektivitas } \\
\text { Vegetasi Reduksi } \\
\text { Kebisingan } \\
\text { Waktu } \\
\text { Maksimum (\%) }\end{array}$ & $\begin{array}{c}\text { Efektivitas } \\
\text { Vegetasi Reduksi } \\
\text { Kebisingan } \\
\text { Waktu Mnimum } \\
\text { (\%) }\end{array}$ \\
\hline \multirow{3}{*}{1} & Senin, 4 Agustus 2014 & \multirow{3}{*}{277,93} & 4,35 & 3,86 & 6,03 & 5,36 \\
\hline & Jumat, 7 Agustus 2014 & & 4,55 & 4,09 & 6,32 & 5,71 \\
\hline & Sabtu, 8 Agustus 2014 & & 3,58 & 3,43 & 4,93 & 4,84 \\
\hline \multirow{3}{*}{2} & Senin, 4 Agustus 2014 & \multirow{3}{*}{0,08} & 3,68 & 3,08 & 5,15 & 4,31 \\
\hline & Jumat, 7 Agustus 2014 & & 4,31 & 3,82 & 5,98 & 5,35 \\
\hline & Sabtu, 8 Agustus 2014 & & 3,15 & 2,62 & 4,35 & 3,69 \\
\hline
\end{tabular}

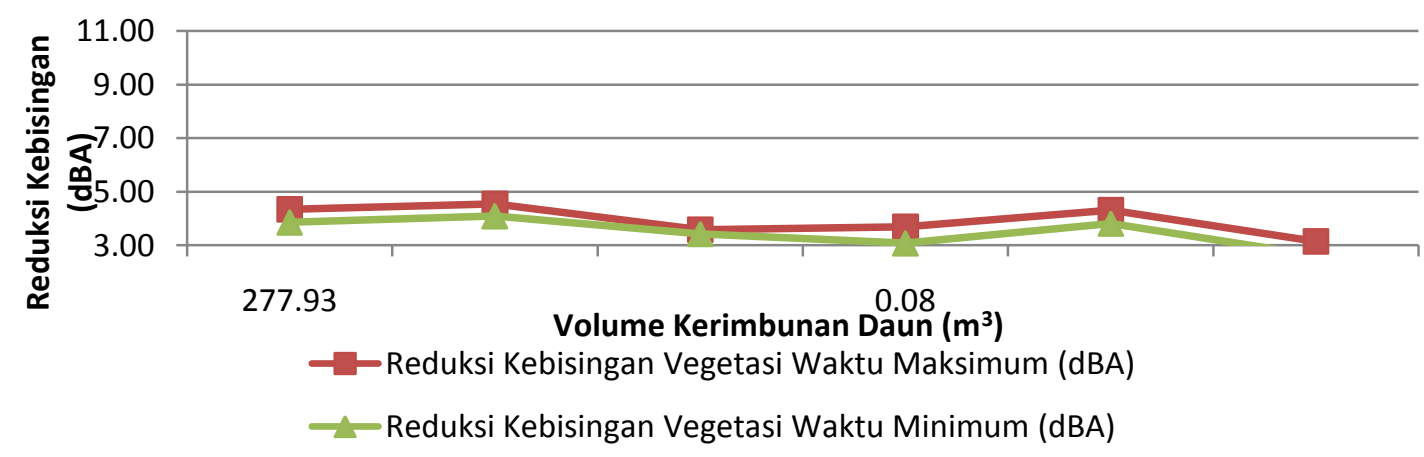

Gambar 7. Grafik Hubungan Volume Kerimbunan Daun dan Reduksi Kebisingan Vegetasi SD S Bruder Nusa Indah

Pengurangan kebisingan pada lokasi ini memang tidak sebesar lokasi sebelumnya, karena kerapatan tumbuh vegetasi rendah. Penghalang vegetasi dengan kerapatan tumbuh tanam tinggi, lebih efektif mereduksi kebisingan dibandingkan penghalang vegetasi yang ditanam dengan kerapatan tumbuh rendah. (Carpenter, 1975 dalam Retno, 2004). Seperti yang pernah dijelaskan oleh Herawati, 1992 dalam Retno 2004, bahwa semakin banyak jumlah baris tanaman dan peningkatan persentasi penutupan tajuk susunan tanaman berkorelasi positif pada besarnya reduksi kebisingan yang dihasilkan.

Dari hasil penelitian, reduksi kebisingan oleh efektivitas vegetasi rendah, 3,69-14,52\%. Disebabkan oleh jenis vegetasi, tingkat kerapatan vegetasi, dan kombinasi penanaman 
vegetasi. Jenis vegetasi berkaitan dengan ketebalan dan kelenturan daun dalam mereduksi kebisingan. Daun akan mudah untuk bergerak karena angin dan energi suara, adanya gerakan daun menyebabkan perubahan posisi antar daun sehingga mempengaruhi ruang antar daun dan memungkinkan suara menembus masuk ke belakang vegetasi. Vegetasi pada lokasi penelitian diantaranya Jambu Bol, Tanjung dan Nangka memiliki bentuk daun tebal dan kaku baik dalam menyerap kebisingan. Tapi, vegetasi ini tidak ditanam dalam jumlah yang banyak.

Kerapatan vegetasi berkaitan dengan massa daun yang padat pada vegetasi berbentuk pohon atau perdu. Tanaman jika cukup tinggi, lebar dan padat, dapat menurunkan tingkat kebisingan, efektivitasnya tergantung pada kerapatan vegetasi dan kepadatan daun. Tanaman pereduksi kebisingan yang efektif dapat mengurangi tingkat kebisingan 10-15 dBA (Kalansuriya, 2009 dalam Primanita Meril, 2012). Vegetasi seperti Angsana, Jambu Bol, Nangka, Pucuk Merah dan Tanjung memiliki tingkat kerapatan daun yang tinggi, mampu mereduksi kebisingan dengan baik, kerapatan daun berhubungan dengan luas bidang penahan rambatan suara. Tapi, penanaman vegetasi tersebut tidak merata, sehingga kemampuannya dalam mereduksi rendah.

Kombinasi penanaman vegetasi, seperti penanaman beberapa spesies dengan kerapatan daun dan ketinggian tumbuh. Vegetasi sebagai penghalang kebisingan harus memiliki kerimbunan dan kerapatan daun yang cukup dan merata mulai dari permukaan tanah hingga ketinggian yang diharapkan. Kombinasi seperti tanaman penutup tanah, perdu, dan pohon, menjadikan vegetasi sebagai efek penghalang lebih optimum. Penanaman beberapa spesies secara bersama-sama lebih efektif dalam mereduksi kebisingan daripada penanaman satu spesies saja (Pedoman Mitigasi Kebisingan PU, 2005). Sudah diterapkan pada ketiga lokasi penelitian, di SMA Sultan Syarif Abdurrahman memiliki tanaman penutup tanah berupa rerumputan, perdu berupa Bunga Bakung, pohon seperti Angsana, Kayu Putih, Nangka dan Tanjung. Tapi, vegetasi di lokasi ini tidak memiliki sebaran daun yang merata hingga permukaan tanah, pohon tinggi sehingga suara lebih mudah masuk menembus ke belakang vegetasi.

Penghalang vegetasi sebagai alternatif pereduksi kebisingan alami, harus mempertimbangkan jenis vegetasi yang ditanam, vegetasi yang memiliki bentuk daun yang tebal dan kaku, memiliki massa daun yang padat dan tajuk yang tebal berkaitan dengan bidang penahan rambatan suara. Selain itu kombinasi vegetasi, mulai dari tanaman penutup tanah, perdu dan pohon. Misalnya rekomendasi tanaman penutup tanah yaitu rumput dan tanaman suku polong-polongan (Leguminosae). Tanaman golongan perdu yaitu bambu pringgodani (Bambusa sp), li kuan yu (Vernonia elliptica), anak nakal (Duranta repens), soka (Ixora sp), kakaretan (Ficus pumila), sebe (Heliconia sp), teh-tehan (Durante). Tanaman pohon yaitu akasia (Acacia mangium), johar (Casia siamea), pohon-pohon yang rimbun dengan cabang rendah. (Pedoman Mitigasi Kebisingan PU, 2005)

Beberapa jenis tanaman meredam suara dengan mengabsorbsi gelombang suara oleh daun, cabang, dan ranting. Jenis tanaman (pohon, perdu/semak) yang paling efektif untuk meredam suara yang mempunyai tajuk yang tebal dan bermassa padat, contohnya Kiara Payung (Felicium desipiens), Teh-tehan pangkas (Acalypha sp), Puring (Codiaeum variegatum), Pucuk Merah (Oleina syzygium), Kembang Sepatu (Hibiscus rosa-sinensis), Bougenville (Bougenville sp), dan Oleander (Nerium oleander). (Pedoman Penanaman Tanaman Di Pinggir Jalan PU, 2012)

\section{Kesimpulan}

1) Berdasarkan perhitungan volume kendaraan di Jalan Ahmad Yani Pontianak, tingkat kebisingan tertinggi adalah 69,78-75,86 dBA, melampaui baku mutu kebisingan yang diperbolehkan untuk kawasan pendidikan yaitu $55 \mathrm{dBA}$. 
2) Berdasarkan perhitungan volume kerimbunan, total volume tertinggi terdapat di SMA Sultan Syarif Abdurrahman pada Plot 2 dengan $102593 \mathrm{~m}^{3}$, jika dihubungkan dengan hasil reduksi kebisingan oleh vegetasi, pengurangannya tidak sebesar di SMK N 5 Pontianak pada Plot 4 yang memiliki total volume kerimbunan $4877 \mathrm{~m}^{3}$. Dikarenakan vegetasi di SMK N 5 Plot 4 memiliki kerapatan tumbuh vegetasi tinggi dan kombinasi penanaman jenis vegetasi. Berbeda dengan vegetasi di SMA Sultan Syarif Abdurrahman, tidak terdapat vegetasi yang memiliki sebaran daun merata hingga permukaan tanah, lebih didominasi vegetasi pohon dengan ketinggian diatas $17 \mathrm{~m}$.

3) Efektivitas vegetasi sebagai peredam kebisingan pada lokasi penelitian tergolong rendah, antara 3,69-16,04\%, dikarenakan jenis vegetasi yang memiliki ciri peredam kebisingan ditanam tidak merata. Jenis vegetasi yang memiliki daun tebal dan kaku, kerapatan daun yang tinggi, dan kombinasi tanaman dengan berbagai tingkatan tinggi dengan massa daunnya merata sampai ke permukaan tanah, tidak ditanam secara merata sehingga penyerapan tidak maksimal.

4) Kawasan pendidikan yang berdekatan dengan aktivitas kendaraan lalu lintas perlu mempertimbangkan penempatan ruangan yang bersifat privat dan publik, ruang privat yang membutuhkan ketenangan seperti ruang kelas, perpustakaan, atau tempat ibadah tidak berdekatan dengan jalan. Ruangan yang bersifat publik seperti ruang guru, ruang administrasi, kantin dapat ditempatkan berdekatan dengan jalan.

\section{Ucapan Terima Kasih}

Penulis mengucapkan terima kasih kepada Allah SWT atas rahmat dan karunia yang telah diberikan selama ini. Kepada kedua orang tua yang tiada hentinya memberikan doa dan semangat dalam menyelesaikan penelitian ini. Kepada Ibu dosen pembimbing, Ibu Mira $S$ Lubis, ST, MT, dan Ibu Sarma Siahaan, S.Si, M.Si, yang memberikan bimbingan dan nasihat, serta kepada Ibu dosen penguji, Ibu Yulisa Fitrianingsih, ST, MT, dan Ibu Bontor Jumaylinda BR Gultom, ST, MT, yang memberikan masukan dalam penyelesaian penelitian ini. Terakhir, untuk teman-teman Teknik Lingkungan Angkatan 2009, terima kasih telah menjadi bagian dalam penyelesaian penelitian ini.

\section{Referensi}

Christina E, 2009. Material Akustik, Pengendali Kualitas Bunyi Pada Bangunan. Yogyakarta.

Liesa A. 2001. Peranan Vegetasi Dalam Mereduksi Kebisingan Jalan Raya. Skripsi. Fakultas Matematika dan IImu Pengetahuan Alam Institut Pertanian Bogor.

[MENLH] Kementerian Lingkungan Hidup. 1996. Keputusan Menteri Lingkungan Hidup No. 48 Tahun 1996 tentang Baku Mutu Tingkat Kebisingan. KepMen-LH-48-1996.pdf.

Pedoman Konstruksi dan Bangunan. 2005. Mitigasi Dampak Kebisingan Akibat Lalu Lintas Jalan. Departemen Pekerjaan Umum.

Pedoman Penanaman Pohon pada Sistem Jaringan Jalan. Peraturan Menteri Pekerjaan Umum No.05/PRT/M/2012.

Primanita M. 2012. Intensitas Kebisingan Berdasarkan Jenis dan Tingkat Kerapatan Tanaman. Skripsi. Fakultas Kesehatan Masyarakat Universitas Muhammadiyah Semarang. Semarang.

Retno Sujatno, 2004. Pengaruh Vegetasi Bambu (Bambusa sp) dan Vegetasi Jati (Tectona grandis) Pada Reduksi Kebisingan. Skripsi. Program Studi Ilmu Lingkungan Universitas Indonesia.

Widagdo, S. 1998. Studi Reduksi Kebisingan Menggunakan Vegetasi dan Kualitas Visual Lanskap Jalan Tol Jagorawi. Program Pasca Sarjana. Institut Pertanian Bogor. Jawa Barat. 